\title{
Potensi Penerapan Konsep Ekologi Industri Untuk Mengatasi Limbah Peternakan Dan Pertanian Kelompok Tani
}

\section{Potential For Implementation Of Industrial Ecology Concept To Overcome}

\author{
Animal Husbandry And Agricultural Waste Agriculture Group \\ Shafwan Amrullah ${ }^{1,3}$ * , Theresia Evila Purwanti Sri Rahayu ${ }^{2}$, Cyrilla Oktaviananda ${ }^{3}$ \\ ${ }^{1}$ Jurusan Teknologi Industri Pertanian, Universitas Teknologi Sumbawa, Jl. Raya Olat Maras, Sumbawa, \\ 84371 Indonesia \\ ${ }^{2}$ Jurusan Teknologi Rekayasa Pengendalian Pencemaran Lingkungan, Politekanik Negeri Cilacap, Jl. Dr. \\ Soetomo No. 1, Cilacap, 53212 Indonesia. \\ ${ }^{3}$ Politeknik Katolik Mangunwijaya, J1. Kusumanegara (Sriwijaya) No. 104, Semarang, 50242, Indonesia. \\ ${ }^{4}$ Pusat Studi Terapan K3L Universitas Teknologi Sumbawa
}

Email: 1'shafwan.amrullah@uts.ac.id, ${ }^{2}$ theresiaevila05@gmail.com, ${ }^{3}$ cyrillaoktaviananda@gmail.com

Direview : 26 Juli 2020

Diterima : 20 Agustus 2020

\begin{abstract}
Abstrak
Sektor pertanian dan peternakan meruapakan penyumbang terbesar kerusakan lingkungan. Dimana dari total sumber gas rumah kaca nasional, sektor pertanian menyumbang 13,6\%. Dari data tersebut, perlu adanya design yang tepat untuk menangani masalah ini. Salah satunya adalah dengan menerapkan konsep ekologi industri sebagai solusi terbaik untuk menangani masalah ini. Sehingga pada penelitian ini dilakuakn perhitungan kuantitatif untuk mengetahui potensi penerapan konsep ekologi industri pada sektor pertanian dan peternakan di Kelompok Tani Tojang Maju 3 yang berlokasi di Kecamatan Masbagik, Kabupaten Lombok Timur, Provinsi Nusa tenggara Barat. Penelitian dilakukan dengan perhitungan kuantitatif limbah yang dihasilkan oleh sektor peternakan serta pertanain kelompok tani, yang selanjutnya dilakukan proses disain model ekologi industrinya. Dari hasil penelitian ini didapatkan disain berupa penggunaan pupuk organik cair (POC) di sektor pertanian sebanyak 280,5 liter untuk padi, 37,4 liter untuk pertanian cabe, dan 37,4 liter untuk pertanian kol serta selebihnya (2.281 liter) dijual sebagai sumber ekonomi kelompok tani. Sedangkan jerami yang dihasilkan oleh pertanian padi $(57.000 \mathrm{~kg})$ digunakan sebagai pembuatan silase di sektor peternakan dengan kebutuhan sebesar 4.957,2 kg. Jerami padi juga dimanfaatkan pada sektor pertanian cabe sebagai mulsa dengan kebutuhan sebesar $1.140 \mathrm{~kg}$ dan selebihnya (50.903 kg) dimanfaatkan sebagai bahan baku produksi gas sintetik untuk sumber energi kelompok tani. Sedangkan sisa hasil pertanian cabe dan kol seluruhnya digunakan sebagai bahan baku biogas dengan massa sekitar $70.300 \mathrm{~kg}$ yang langsung dimanfaatkan oleh kelompok tani sendiri. Untuk fases sapi sebanyak $5.355 \mathrm{~kg}$ diumpankan ke digester biogas sebagai bahan baku biogas peternakan untuk konsumsi kelompok tani, dengan potensi gas sebesar 535,5 $\mathrm{m}^{3}$. Dengan hasil tersebut dapat dikatakan bahwa, konsep ekologi industri akan berdampak sangat baik dalam menangani bahkan mengeliminasi timbunan limbah dari sektor pertanian dan peternakan terutama di Kelompok Tani Tojang Maju 3.
\end{abstract}

Kata kunci: krisis lingkungan, ekologi industri, pertanian, peternakan, limbah 


\begin{abstract}
The agriculture and livestock sector is the biggest contributor to environmental damage. Where from the total national sources of greenhouse gases, the agricultural sector accounted for $13.6 \%$. From this data, there needs to be an appropriate design to deal with this problem. One way is to apply the concept of industrial ecology as the best solution to deal with this problem. So that in this study quantitative calculations were carried out to determine the potential application of the concept of industrial ecology in the agriculture and animal husbandry sector in the Tojang Maju 3 Farmer Group located in Masbagik District, East Lombok Regency, West Nusa Tenggara Province. The study was conducted with a quantitative calculation of waste generated by the livestock sector as well as farmer group questions, which then carried out the design process of the industrial ecological model. The results obtained the use of liquid organic fertilizer (POC) in the agricultural sector as much as 280.5 for rice, 37.4 for chilli farming, and 37.4 liters for cabbage farming and the rest as sources of economics. Whereas straw produced by rice farming $(57,000 \mathrm{~kg})$ is used as silage in the livestock sector with a demand of 4,957.2 kg. Rice straw is also used in the chilli agriculture sector as mulch with a requirement of $1,140 \mathrm{~kg}$ and the rest $(50,903 \mathrm{~kg})$ is used as raw material for the production of synthetic gas for energy sources of farmer groups. While the rest of the chilli and cabbage agricultural products are used as raw material for biogas with a mass of around 70,300 kg which is directly utilized by the groups. For cow as much as 5,355 $\mathrm{kg}$ is fed to the biogas digester as biogas for the consumption of farmer groups, with a gas potential of $535.5 \mathrm{~m}^{3}$.
\end{abstract}

Keywords: Environmental crisis, industrial ecology, agriculture, animal husbandry, waste

\title{
1. PENDAHULUAN
}

Limbah yang dihasilkan dari sektor pertanian sangat berlimpah, hal ini didukung oleh Indoneisa sebagai Negara agraris, dengan sektor pertanian sebagai penyumbang terbesar sampah organik. Dimana luas lahan pertanian Indonesia sangat besar, ditambah lagi karena proses deforestasi sehingga terjadi penambahan lahan sebesar 358.000 hektar. Sampai saat ini lahan pertanian Indonesia mencapai 7,105 juta hektar (Faqir, 2018). Dengan begitu, penambahan limbah hasil pertanianpun secara otomatis terus bertambah. Di Pulau Lombok sendiri memiliki lahan pertanian yang cukup besar. Dan yang terbesar adalah di Lombok timur, yaitu mencapai 47.312 hektar pata tahun 2014, yang terbagi menjadi lahan tadah irigasi dan non irigasi (BPS-PNTB, 2014). Dengan data tersebut, secara otomatis menyebabkan produksi limbah oleh sektor pertanian tersebut. Dari hasil penelitian Acker (1971), limbah pertanian dapat dibagi menjadi 3 berdasarkan kandungan proteinnya. Antara lain adalah kandungan protein kurang yang terdiri dari sekitar $10 \%$ protein, kandungan protein sedang dengan kandungan $10-18 \%$ protein, serta kandungan protein berlebih yang mengandung sekitar $18 \%$ protein. Secara spesifik, hasil penelitian tentang analisis proximate terhadap berbagai macam limbah pertanian di Indonesia telah dilakukan. Dimana sebagaian besar kandungan limbah pertanian di Indonesia adalah terdiri dari gizi serat kasar (SK), protein kasar (PK), lemak kasar (LK), bahan ekstrak tanpa nitrogen (BETN), dan juga kadar abu. Penelitian sebelumnya juga telah dihasikan kandungan proximate beberapa limbah pertanian di Indonesia, seperti pada Tabel 1. 
Tabel 1. Analisi Hasil Uji Proximate Limbah Pertanian di Berbagai Daerah Di Indoneisa (UPVAP, 2016)

\begin{tabular}{|l|l|l|l|l|l|}
\hline Bahan & SK & PK & LK & BETN & Abu \\
\hline $\begin{array}{l}\text { Jerami ubi } \\
\text { jalar }\end{array}$ & 16,20 & 19,20 & 2,60 & 45,90 & 16,10 \\
\hline Jerami padi & 31,38 & 5,61 & 1,72 & 29,14 & 18,44 \\
\hline Dedak kasar & 31,54 & 5,62 & 3,42 & 31,43 & 18,53 \\
\hline Dedak halus & 27,50 & 9,23 & 1,83 & 39,77 & 16,12 \\
\hline Kaliandra & 19,80 & 25,00 & 2,48 & 47,20 & 5,90 \\
\hline Lamtoro & 20,10 & 31,74 & 8,76 & 30,48 & 5,22 \\
\hline $\begin{array}{l}\text { Daun } \\
\text { pepaya }\end{array}$ & 24,51 & 8,06 & 6,77 & 43,68 & 7,25 \\
\hline Kulit nanas & 29,25 & 7,92 & 6,68 & 31,53 & 7,25 \\
\hline $\begin{array}{l}\text { Bungkil } \\
\text { kelapa }\end{array}$ & 15,38 & 18,58 & 12,55 & 37,26 & 6,36 \\
\hline Daun pisang & 38,23 & 7,77 & 5,18 & 24,19 & 14,14 \\
\hline Bekatul & 5,72 & 10,77 & 10,97 & 57,41 & 2,74 \\
\hline
\end{tabular}

Sedangkan untuk limbah hasil peternakan di Indonesia juga sangat banyak. Limbah ternak pada umumnya merupakan sisa buangan dari sebuah usaha yang bergerak dibidang peternakan seperti pemeiharaan ternak, rumah potong hewan, dan juga pengolahan produk hasil dari peternakan. Yang tergolong dalam limbah peternakan secara spesifik meliputi limbah padat dan limbah cair. Limbah padat berupa fases, sisa makanan, embrio, kuilit telur, lemak, bulu, kuku, tulang, tanduk, dan lain sebagainya (Sihombing, 2000). Dari beberapa jenis peternakan yang ada, peternakan sapi merupakan penhasil limbah terbesar di Indonesia, termasuk yang dihasilkan oleh Kelompk tani Tojang maju 3 Lombok Timur. Dimana limbah yang dihasilkan terbesar berupa feses dan urin. Secara umum, limbah yang dihasilkan pada setiap peternakan sapi adalah $2 \mathrm{~kg}$ feses pada setiap kilogram susu yang dihasilkan. Selain itu terhitung pula setiap 1 kilogram daging sapi atau kerbau menghasilkan $25 \mathrm{~kg}$ feses (Sihombing, 2000). Dari data ini, dengan bertambahnya jumlah peternakan sapi, tentunya akan menambah jumlah limbah. Sedangkan diketahui bahwa limbah peternakan ini sangat berbahaya bagi lingkungan. Seperti hasil pengamatan yang dilakukan oleh Oginawati dkk. (2013). Dimana urin sapi dapat mencemari daerah aliran sungai (DAS) di daerah Cikapundung. Dimana limbah cair peternakan di sekitar daerah tersebut dapat menyebabkan DAS memiliki nilai BOD 981,388 mg/l dan kadar COD $2970,3 \mathrm{mg} / \mathrm{l}$.

Dari permasalahan yang timbul seperti yang telah dijelaskan tersebut, perlu adanya langkah dalam mengatasi limbah pertanian dan peternakan tersebut. Telah banyak upaya yang dilakukan, saah satunya mengkonversi limbah peternakan berupa feses menjadi biogas ataupun pupuk. Selain itu, limbah pertanian seperti ranting tanaman dan batok kelapa dapat dimanfaatkan sebagai energi terbarukan berupa gas sintetik maupun bio-oil (Amrullah dkk., 2017). Akan tetapi, dengan melakukan konversi dengan terpisah akan menyebabkan sulitnya keberlanjutan dari kegiatan tersebut sehingga keuntungan secara ekonomi sulit terlihat. Saat ini metode yang paling efektif dapat dilakukan adalah dengan menghubungkan metode konversi limbah pertanian dan peternakan menjadi model terintegrasi. Hal ini sejalan dengan apa yang dikatakan oleh Partiwiningrum (2019), yaitu perlu adanya revialisasi pengelolaan limbah peternakan dan hasil ikutannya yang ramah lingkungan dan berorientasi ekonom dengan prinsip Reduce, Reuse, Recyce. Selain itu juga perlunya revitalisasasi terhadap limbah peternakan dengan mengacu pada circualar economy atau yang biasa disebut dengan ekkonomi siklus, dimana siklus ini merupakan praktik bisnis yang menguntungkan dengan memanfaatkan limbah dan produk samping dari aktivitas peternakan tersebut. Untuk melakukan hal tersebut telah dikembangkan metode pengolahan limbah yang berkesinambungan, yang dikenal dengan istilah Ekologi Industri. 
Konsep Ekologi Industri awalnya diperkanalkan sebagai konsep yang digunakan untuk melakukan proses effisiensi terhadap permasalah ekologi yang disebabkan karena pembuangan limbah suatu industri (Mena dkk., 2016). Secara umum ekologi industri berbicara tentang interaksi antara masyarakat, industri serta lingkungan. Dimana tujuan utamanya adalah menyelaraskan antara aspek lingkungan, manajemen industri, ekonomi, hingga sosiologis (Allenby and Graedel, 1993). Secara sederhana, konsep ini bertujuan untuk mengurangi limbah industri dengan memanfaatkan limbah yeng merupakan bahan baku untuk industri turunannya. Sebagai contoh, dengan memanfaatkan hasil industri pertanian untuk pembuatan kompos organik, sehingga dapat digunakan oleh industri pupuk untuk menghasilkan pupuk organik yang bernilai ekonomi tinggi dan dapat dikembalikan ke pertanian. Selain masalah lingkungan, dengan melihat tujuan dan bentuk konsep Ekologi Industri, beberapa permasalahan dapat dipecahkan, terutama masalah energi dan ekonomi. Salah satunya adalah pemanfaatan limbah organik atau limbah peternakan sapi sebagai biogas yang dihasilkan dari proses anaerobik (Tang dkk., 2016).

Sehingga, penelitian ini bertujuan untuk melakukan evaluasi dan perancangan konsep Ekologi Industri dalam mengatasi masalah lingkungan yang dihasilkan dari limbah pertanian dan peternakan Kelompok Tani Tojang Maju 3, Kecamatan Masbagik, Kabupaten Lombok timur, Nusa Tenggara Barat. Penelitian dilakukan dengan sistem perhitungan kuantitatif berupa pengukuran secara nyata di lapangan, wawancara, dan studi pustaka. Hasil dari penelitian ini berupa disain menyeluruh tentnag penerapan konsep Ekolohi Industri dalam rangka mewujudkan sistem pertanian dan peternakan terintegrasi.

\section{METODE PENELITIAN}

\subsection{Waktu dan Lokasi Penelitian.}

Penelitian dilakukan pada bulan November-Januari 2019. Bulan ini adalah masa tanam pertama dengan dominasi pertanian padi. Lokasi penelitian adalah di wilayah tanam dan lokasi peternakan sapi Kelompok Tani Tojang Maju 3, Kecamatan Masbagik, Kabupaten Lombok Timur, Provinsi Nusa Tenggara Barat. Lokasi dapat dilihat pada Gambar 1. Dari Gambar 1, sektor peternakan terdiri dari 8 sapi dengan usia 2,5 tahun dan 1 sapi dengan usia 1 tahun. Sedangakan pada sektor pertanaian melibatkan tanah pertanian seluas 15,20 hektar, dengan 11,4 hektar untuk pertanian jenis padi, 2,28 hektar untuk cabe, dan 1,52 hektar untuk kol.

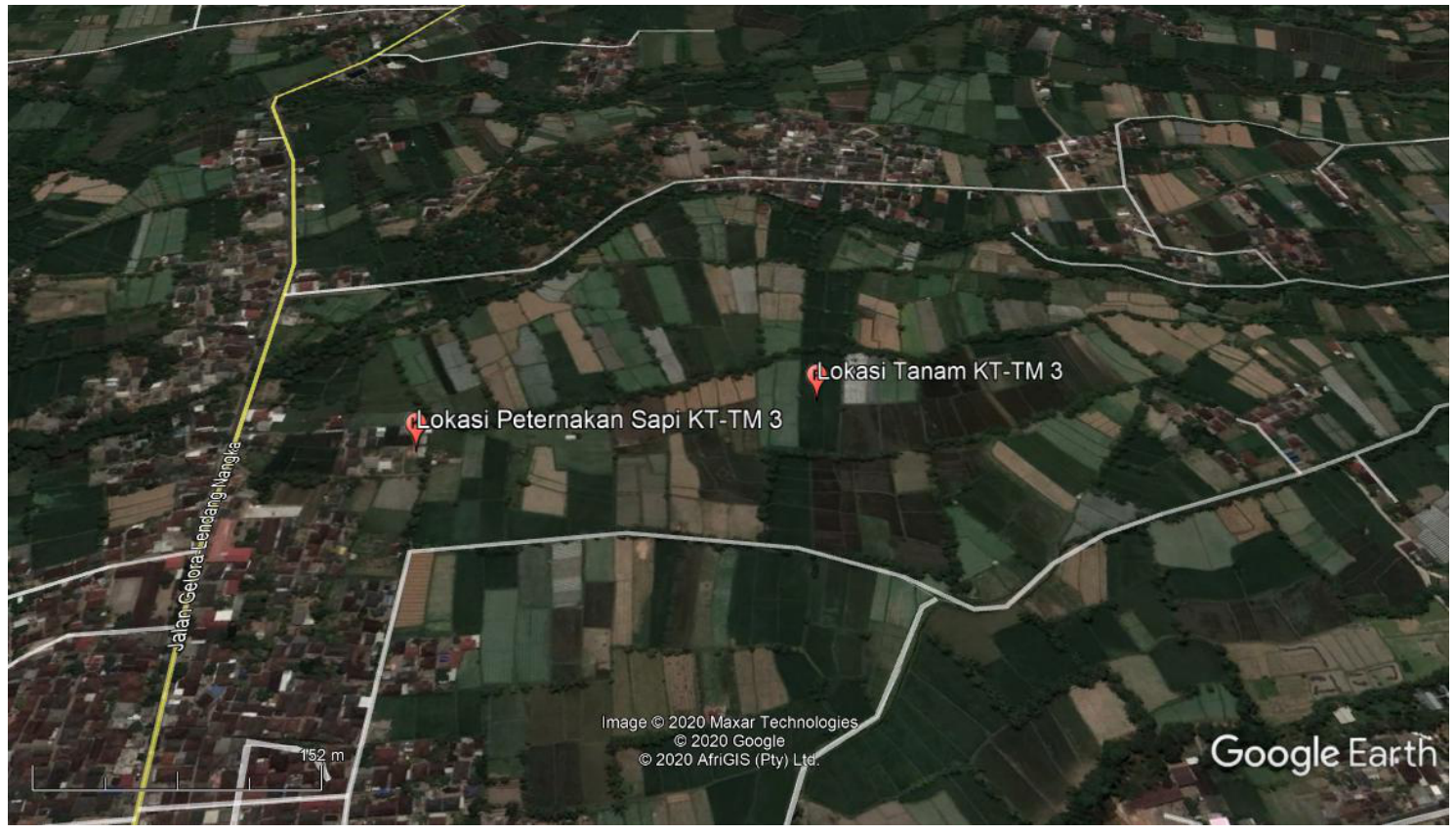

Gambar 1. Lokasi Peternakan dan Lokasi Tanam Kelompok Tani Tojang Maju 3 


\subsection{Prosedur Penelitian}

Penelitian ini dibagi menjadi tiga langkah utama. Yang pertama adalah dengan mengevaluasi jumlah limbah yang dihasilkan sektor peternakan. Yang kedua adalah dengan menghitung jumlah limbah yang dhasilkan oleh sektor pertanian, serta yang terkahir adalah pembuatan design model ekologi industri yang menggabungkan antara sektor peternakan dan sektor pertanian di Kelompok Tani Tojang Maju 3.

Pada proses evaluasi limbah peternakan diakukan dengan studi lapangan, yaitu dengan langsung mengukur beberapa aspek yang terjangkau, seperti limbah hasil peternakan berupa jumlah urin yang dihasilkan per hari serta jumlah feses yang dibuang setiap hari oleh seluruh sapi yang ada di peternakan. Hal ini agar kuantitas dari limbah peternakan di Kelompok Tani Tojang Maju 3 diketahui. Selain itu melakukan proses wawancara terhadap para peternak tentang jumah dan jenis pakan yang biasa diberikan ke sapi setiap harinya. Pada bagian akhir membuat neraca massa dari sektor peternakan itu sendiri. Di lain pihak juga dilakukan studi pustaka untuk mengetahui nilai gizi yang ada pada pakan ternak sehingga design model dapat dilakukan dengan baik.

Evaluasi limbah pertanian diakukan dengan studi lapangan berupa pengambilan data luas sawah yang dimiliki oleh Kelompok Tani Tojang Maju 3. Selain itu dilakukan proses pengambilan data tentang jenis tanaman yang ditanam selama periode penelitian. Setelah itu dilanjutkan dengan pengambilan data jumlah limbah yang dihasilkan setiap jenis tanaman setiap satuan luas sawah untuk mengkaji secara pustaka tentang kandungan proximate dari setiap limbah pertanian yang dimiliki. Di akhir evaluasi dilakukan pembuatan neraca massa dari sektor pertanaian.

Pada proses design dilakukan dengan membuat diagram konsep Ekologi Industri dari gabungan antara limbah yang dihasilkan dari sektor peternakan dan juga sektor pertanian Kelompok Tani Tojang Maju 3. Disain yang diakukan dilengkapi dengan rekomendasi yang tepat dalam rangka melakukan efisiensi massa dan ekonomi.

\section{HASIL DAN PEMBAHASAN}

\subsection{Hasil Evaluasi Sektor Peternakan Kelompok Tani Tojang maju 3}

Hasil penelitian limbah pada sektor peternakan Kelompok Tani Tojang Maju 3 dapat dilihat pada Tabel 2.

Tabel 2. Aliran Massa Sektor Peternakan Kelompok Tani Tojang Maju 3 Pada Bulan NovemberJanuari

\begin{tabular}{|l|l|l|l|l|}
\hline \multirow{2}{*}{ Jenis bahan } & \multicolumn{2}{|c|}{ Input } & \multicolumn{2}{c|}{ Output } \\
\cline { 2 - 5 } & $\mathrm{Kg} / \mathrm{hari}$ & $\mathrm{Kg} / 3$ bulan & $\mathrm{Kg} / \mathrm{hari}$ & $\mathrm{Kg} / 3$ bulan \\
\hline Jerami & 127 & 11.430 & 25,5 & 2.295 \\
\hline Feses & 0 & 0 & 59,5 & 5.355 \\
\hline Urin & 0 & 0 & $29,5^{*}$ & $2.655^{*}$ \\
\hline
\end{tabular}

*Dalam satuan Liter

Dari data pada Tabel 2, jerami merupakan pakan ternak yang selalu digunakan sebagai pakan untuk sapi di Kelompok Tani Tojang Maju 3. Dari data tersebut, terlihat bahwa jerami yang digunakan sebagai pakan sangat banyak, hal ini karena jerami yang digunakan adalah jerami basah. Dan dari data tersebut juga terlihat ada sisa dari pakan ternak, hal ini terjadi karena pakan sudah terlanjur layu sebelum pakan habis dikonsumsi oleh sapi, sehingga pakan tidak termakan seluruhnya. Dengan begitu, perlu adanya inovasi dalam mengatasi keterbuangan pakan ini. Salah satu cara untuk mengatasinya adalah dengan membuat silase dari jerami tersebut. Dimana silase dibuat dengan tujuan mengawetkan pakan ternak. Silase dibuat dengan metode fermentasi anaerob. Silase yang bagus terbuat dengan fermentasi yang didominasi oleh bakteri yang dapat menghasilkan asam laktat dengan cara menekan aktivitas dari bakteri colostridia (Hidayat, 2014). Dari penelitian sebelumnya telah diketahui bahwa kebutuhan pakan 
silase sapi pedaging dengan kualitas terbaik adalah $6,12 \mathrm{~kg}$ silase jerami untuk setiap sapi per harinya (Usia 1,5-2,5 tahun) (Eslamizad dkk., 2020). Sehingga Kelompok Tani Tojang Maju 3 hanya membutuhkan jerami sekitar $4.957,2 \mathrm{~kg} / 3$ bulan, dan menghemat penggunaan jerami sebesar $6.457,8$ $\mathrm{kg} / 3$ bulan. Data ini berdasarkan pada kandungan air pada jerami padi yang basah adalah sebesar $35 \%$ (Hidayat dkk., 2006).

Untuk limbah urin sapi yang dihasilkan oleh peternakan Kelompok Tani Tojang Maju 3, dimana berdasarkan pada data pada Tabel 2 sangatlah besar, yaitu hingga mencapai 2.655 liter dalam tiga bulan. Hal ini sangat berefek terhadap pencemaran lingkungan. Dimana pembuangan urin sapi ke Daerah Aliran Sungai dapat meningkatkan nilai COD dan BOD secara drastis. Dengan masalah seperti ini perlu adanya inovasi dalam mengelola limbah tersebut, salah satunya adalah dengan memanfaatkan urin sebagai pupuk organik cari (POC). POC dapat dibuat dengan bantuan mikroorganisme anaerobik yang telah ada, misalkan EM4. Hasil dari fermentasi urin sapi ini berdasarkan hasil penelitian sebelumnya menghasilkan POC dengan kadar N 2,7\%, P 2,4\%, K 3,8\%, Ca 5,8\%, Na 7,2\%, Mn 507\%, Zn 624\%, dan $\mathrm{Cu}$ 510\% (Mirna dkk., 2013). Dengan mengacu pada PERATURAN MENTERI PERTANIAN RI No. 80 tahun 2011, kriteria pupuk organik cair yang dihasilkan dari limbah urin sapi tersebut telah dapat mencukupi kebutuhan unsur hara tanah. Sedangkan, dengan mengacu pada hasil penelitian bahwa kebutuhan pupuk cair dari urin sapi adalah sekitar 14.000 liter untuk 600 hektar lahan pertanian padi (24 liter/hektar/masa tanam) (Ambari, 2018). Sehingga dengan mengacu pada luas lahan yang ada di Kelompok Tani Tojang Maju 3 (15,2 hektar), pupuk cair yang dihasilkan dari peternakan kelompok tani (2.655 liter) sudah dapat mensuplai kebutuhan pupuk tanaman, yaitu hanya sekitar 374 liter. Sehingga dengan begitu, terjadi surplus pupuk cair hingga $710 \%$. Hal ini dapat dimanfaatkan oleh kelompok tani sebagai sumber ekonomi baru, yaitu dengan menjual POC seharga Rp 7.000-Rp 8.000/liter (Mappanganro dkk., 2018).

Sedangkan untuk limbah feses sapi yang dihasilkan oleh peternakan Kelompok Tani Tojang Maju 3 menurut Tabel 2 juga begitu banyak, hal ini menyebabkan kerusakan lingkungan yang sangat serius. Dimana dengan pembuangan limbah feses ke lingkungan, dapat menyebabkan nilai COD perairan meningkat menjadi 20-80 mg/liter, dengan maksimal COD yang diizinkan maksimal $10 \mathrm{mg} / \mathrm{L}$. Selain itu juga pembuangn feses ke lingkungan meningkatkan nilai TSS hingga 64-94 mg/L dari batas maksimum TSS adalah $50 \mathrm{mg} / \mathrm{L}$ (Saputra, 2017). Dengan begitu perlu adanya konversi limbah feses tersebut menjadi bahan yang berguna. Saat ini telah dilakukan konversi feses menjadi biogas dan juga aktivator pembuatan pupuk kompos dari sisa dedaunan hasil pertanian. Akan tetapi dengan keberlimpahan pupuk cair dari urin sapi, pada Kelompok Tani Tojang Maju 3 diperuntukkan untuk bahan bakar biogas hanya cukup untuk konsumsi anggota kelompok tani saja. Dari penelitian sebelumnya diketahui bahwa kotoran sapi dapat menghasilkan $2 \mathrm{~m}^{3}$ biogas untuk setiap 10-20 kg feses, dimana untuk $1 \mathrm{~m}^{3}$ menghasilkan energi sebesar 2.000-4.000 kkal atau dapat memenuhi kebutuhan memasak bagi satu keluarga selama 6 jam (Hanif dan Andi, 2011). Sehingga dengan mengacu pada jumlah feses yang dihasilkan oleh Kelompok Tani Tojang Maju 3 selama 3 bulan sebesar $5.355 \mathrm{~kg}$, dapat menghasilkan biogas sebanyak 535,5 $\mathrm{m}^{3}$, dengan energi sebesar $1.606 .500 \mathrm{kkal}$. Sehingga dengan perhitungan di atas, produksi feses seperti itu dapat mensuplai gas untuk 3 keluarga dalam 3 bulan.

\subsection{Hasil Evaluasi Sektor Pertanian Kelompok Tani Tojang Maju 3}

Hasil penelitian limbah pada sektor pertanian Kelompok Tani Tojang Maju 3 dapat dilihat pada Tabel 3. 
Tabel 3. Airan Massa di sektor pertanian Kelompok Tani Tojang Maju 3 pada Bulan NovemberJanuari

\begin{tabular}{|l|l|l|l|l|}
\hline \multirow{2}{*}{ Jenis bahan } & \multicolumn{3}{|c|}{ Input } & \multicolumn{2}{c|}{ Output } \\
\cline { 2 - 5 } & Kg/hari & $\mathrm{Kg} / 3$ bulan & $\mathrm{Kg} / \mathrm{hari}$ & $\mathrm{Kg} / 3$ bulan \\
\hline Padi & - & - & - & 39.900 \\
\hline Jerami & - & - & - & 57.000 \\
\hline Cabe & - & - & - & 20.520 \\
\hline Jerami Cabe & - & - & - & 51.300 \\
\hline Kol & - & - & - & 76.000 \\
\hline Jerami kol & - & - & - & 19.000 \\
\hline $\begin{array}{l}\text { Pupuk Urea } \\
\text { dan TS }\end{array}$ & - & 2.280 & - & 1.596 \\
\hline $\begin{array}{l}\text { Pupuk Cair } \\
\text { (NPK, } \\
\begin{array}{l}\text { Masitem, } \\
\text { Ponska, } \\
\text { Urea) }\end{array}\end{array}$ & - & 1.140 & - & 798 \\
\hline
\end{tabular}

Berdasarkan pada Tabel 3, dapat dilihat bahwa terjadi aliran massa limbah yang besar dari hasil kegiatan pertanian Kelompok Tani Tojang Maju 3. Dari Tabel 1, jerami padi yang dihasilkan sangat besar, yaitu mencapai $57.000 \mathrm{~kg} / 3$ bulan. Hal ini sangat berpotensi untuk dijadikan sebagai pakan ternak sapi, sebab jumlahnya yang berlimpah serta kandungan unsur kimia yang dibutuhkan oleh sapi dapat terpenuhi. Selebihnya dapat disuplai ke tanaman cabe dan kol sebagai pengganti mulsa dari plastik yang kurang baik terhadap tanah. Yaitu dengan kembali menggunakan mulsa organik dari jerami yang telah dicacah dapat meningkatkan produktifitas tanah, hal ini terjadi karena jerami tidak hanya berfungsi sebagai pelindung tanah dari serangan hama, tetapi juga sebagai pupuk. Seperti penelitian yang dihasilkan oleh Harsono (2012) yang mengatakan bahwa aplikasi mulsa organik pada musim kering dapat meningkatkan pertumbuhan tanaman berdasarkan jumlah cabang dikotomi, luas area daun, bobot kering tanaman, laju asimilasi bersih, laju pertumbuhan relative, panjang buah dan hasil buah yang lebih baik. Dari hasil perhitungan di lapangan, mulsa yang dibutuhkan setiap hektar adalah $300 \mathrm{~kg}$. Sehingga dengan luas total tanah pertanian cabe dan kol sebesar 3,7 hektar membutuhkan mulsa sebanyak 1.140 $\mathrm{kg}$ jerami/ 3 bulan. Sedangkan sisa dari jerami bersamaan dengan jerami yang dihasilkan oleh jerami tomat dan kol untuk menghasilkan biogas dan juga syngas untuk bahan bakar (Park dkk., 2020). Dimana biogas dari bahan baku sampah organik dapat dibuat dengan menggunakan alat digaster dengan bantuan mikroorganisme penghasil metan. Sedangankan gas sintetik dibuat menggunakan alat bernama gasifier dengan bantuan panas (Herlambang dkk., 2018). Jumlah bahan organik yang digunakan sebagai biogas dan gas sintetik merupakan gabungan dari jerami padi, jerami cabai, dan jerami kol. Jumlahnya adalah $120.903 \mathrm{~kg} / 3$ bulan.

Selain limbah organik, sisa kegiatan pertanian Kelompok Tani Tojang Maju 3 adalah berupa sisa dari penggunaan pupuk sintetik. Hal ini terjadi karena penyerapan pupuk sintetik oleh tumbuhan hanya sekitar $30 \%$, dan sisanya akan terpapar ke tanah dan mengakibatkan kerusakan tanah serta pemanasan global. Dimana dari hasil penelitiannya mengatakan bahwa sektor pertanian menyumbangkan 13,6\% terhadap total penyebab Gas Rumah Kaca (GRK) Nasional (Kartikawati dan Nursyamsi, 2013). Sehingga pada Kelompok Tani Tojang Maju 3 mengganti penggunaan pupuk sinteteik dengan pupuk organik cair (POC) dari fermentasi urin sapi. 


\subsection{Design Konsep Ekologi Industri di Sektor Pertanian dan Peternakan Kelompok Tani Tojang Maju 3}

Design akhir dari konsep Ekologi Industri di sektor pertanian dan peternakan Kelompok Tojang Maju 3 berdasarkan perhitungan aliran massa dan energi dapat dilihat pada Gambar 2.

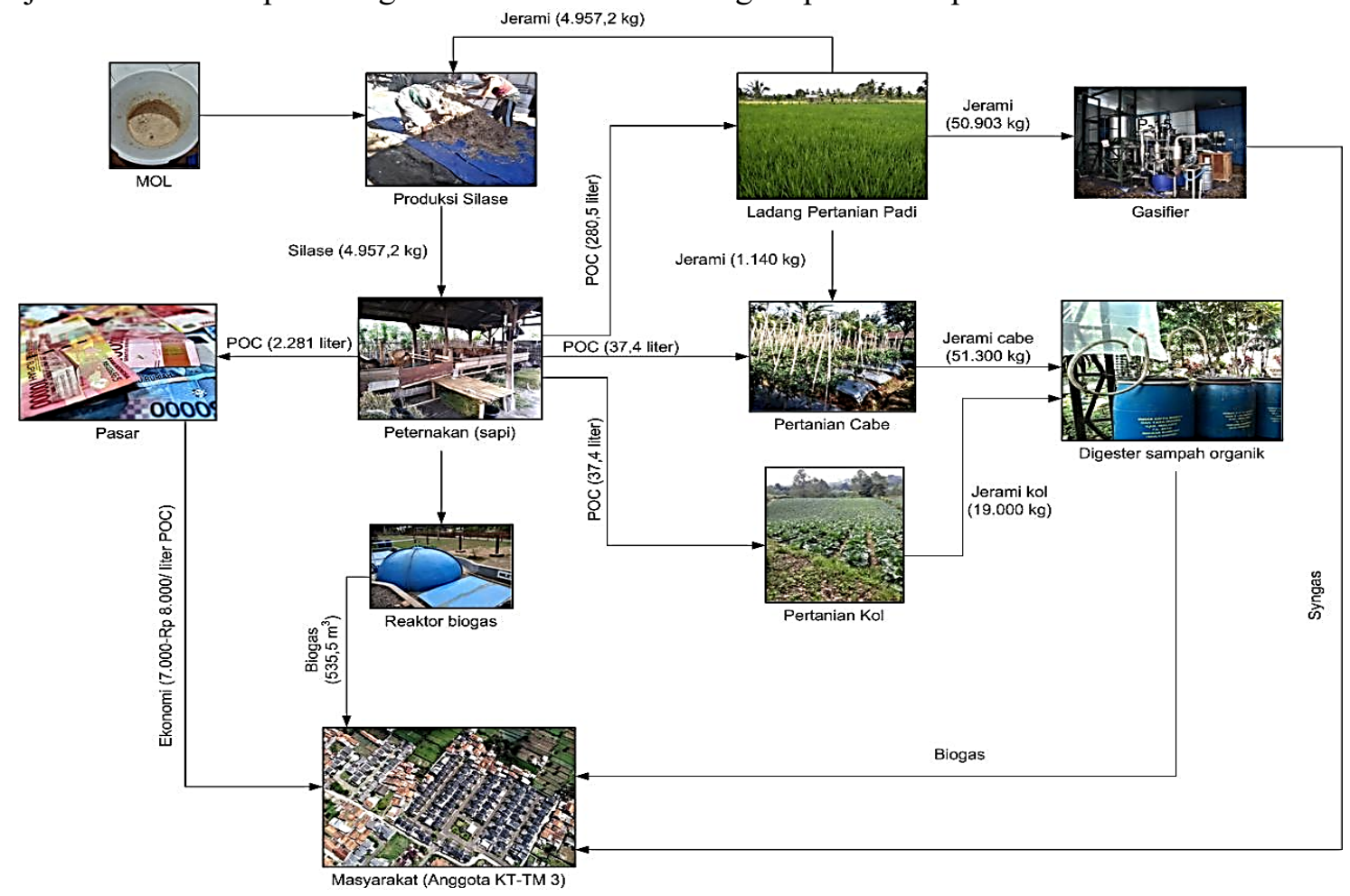

Gambar 2. Disain Konesp Ekologi Industri Sektor Pertanian dan Peternakan Kelompok Tani

Tojang Maju 3

Dari gambar 2 terlihat bahwa disain konsep Ekologi Indutri untuk mengatasi masalah limbah yang dihasilkan oleh kegiatan peternakan dan pertanian Kelompok Tani Tojang Maju 3. Dari Gambar 2 juga dapat dilihat bahwa dari hasil evaluasi terhadap sektor pertanian dan peternakan, dihasilkan disain konsep ekologi industri yang terintegrasi dengan baik. Yaitu dengan memanfaatkan limbah urin peternakan sapi sebagai pupuk orgnik cair yang digunakan pada pertanian padi, cabe, dan kol serta kelebihannya dijual sebagai sumber pendapatan kolompok tani. Sedangkan feses sapi yang dihasilkan dapat dimanfaatkan sebagai biogas untuk konsumsi rumah tangga kelompok tani. Selain itu jerami padi dapat digunakan sebagai pembuatan silase untuk pakan ternak sapi.Selebihnya jerami dapat dimanfaatkan sebagai mulsa organik untuk pertanian cabe serta sebagai bahan baku gasifikasi dan menghasilkan gas sintetik untuk mensuplai kebutuhan anggota kelompok tani akan bahan bakar gas. Di lain pihak, pupuk organik cair yang dihasilkan dari urin sapi dapat digunakan pada sektor pertanian cabe dan kol. Sedangkan sisa pertanian cabe dan kol ini teridiri dari batang dan daun yang dimanfaatkan untuk pembuatan biogas untuk komsumsi rumah tangga kelompok tani juga.

\section{KESIMPULAN}

Pada penelitian ini dihasilkannya konsep Ekologi Industri yang dapat mengurangi bahkan meniadakan pembuangan limbah sisa peternakan dan pertanian di Kelompok Tani Tojang Maju 3. Dimana disain yang dihasilkan berupa penggunaan pupuk organik cair (POC) di sektor pertanian sebanyak 280,5 liter untuk padi, 37,4 liter untuk pertanian cabe, dan 37,4 liter untuk pertanian kol serta selebihnya (2.281 liter) dijual sebagai sumber ekonomi kelompok tani. Setelah itu jerami yang dihasilkan oleh pertanian padi (57.000) digunakan sebagai 
pembuatan silase dengan kebutuhan sebesar 4.957,2 kg. Jerami padi juga dimanfaatkan pada sektor pertanian cabe sebagai mulsa dengan kebutuhan sebesar $1.140 \mathrm{~kg} / 3$ bulan. Sedangkan selebihnya $(50.903 \mathrm{~kg})$ dimanfaatkan sebagai bahan baku pembuatan gas sintetik untuk sumber gas bakar bagi kelompok tani. Selain itu sisa hasil pertanian cabe dan kol seluruhnya digunakan sebagai bahan baku biogas yaitu sebesar $70.300 \mathrm{~kg}$ yang dimanfaatkan oleh kelompok tani sendiri. Untuk fases sapi pada penelitian ini diumpankan ke digester biogas sebagai bahan baku biogas peternakan untuk konsumsi kelompok tani.

\section{SARAN}

Perlu adanya pengembangan lebih lanjut dan uji secara lengkap dan menyeluruh. Selain itu, perlu adanya penerapan konsep agar masyarakat dapat mengetahui dampak nyata dari hasil penerapan tersebut.

\section{PENGHARGAAN}

Terimakasih kepada pengurus Kelompok Tani Tojang Maju 3 yang telah bekerjasama dan menyediakan data yang dibutuhkan dalam penelitian ini.

\section{DAFTAR PUSTAKA}

Amrullah, S., Perdan, I., \& Budiman, A. (2017). Study on Performance and Environmental Impact of Sugarcane-Bagasse Gasification. In Joint International Conference on Science and Technology in The Topic (pp. 121-127). Mataram, Indonesia: University of Mataram, University of Malaya, Indonesia.

BPS-PNTB. Luas Lahan Sawah Menurut Kabupaten/Kota dan Jenis Pengairan di Provinsi Nusa Tenggara Barat (hektar), 2014. https://ntb.bps.go.id/. (23 Juli 2020)

Herlambang, A., Amrullah, S., Daniyanto, D., Pradana, Y.S., Rochmadi, \& Budiman, A. (2018). Biomass pre-treatment on non-catalytic gasification of Indonesian sugarcane bagasse. AIP Conference Proceedings 2026, 020032. Indonesia.

Park, J.G., Kwon, H.J., Sposob, M., \& Jun, H.B. (2020). Effect of a side-stream voltage supplied by sludge recirculation to an anaerobic digestion reactor. Bioresource Technology, 300, 122643, 110 .

Mappanganro, R., Kiramang, K., \& Kurniawan, M.D. (2018). Pemberian Pupuk Organik Cair (Urin Sapi) terhadap Tinggi Pennisetum purpureum cv. Mott. Jurnal Ilmu dan Industri Peternakan, 4 (1), 23-31.

Mirna, M., Salim, H., \& Gani, Z.F. (2013). Pengaruh Biourine Sapi Terhadap Pertumbuhan Bibit Karet (Hevea Brasiliensis Mull. Arg) Asal Stum Mata Tidur. Bioplantae, 2 (1), 27-32.

Tang, J., Wang, X., Hu, Y., Zhang, Y., Li, Y., 2016. Lactic acid fermentation from food waste with indigenous microbiota: effects of $\mathrm{pH}$, temperature and high OLR. Waste Management, 52, 278285.

Eslamizaed, M., Albrecht, \& D., Kuha, B. (2020). The effect of chronic, mild heat stress on metabolic changes of nutrition and adaptations in rumen papillae of lactating dairy cows. Journal of Dairy Science, 103, (9).

Faqir, A.A. Luas Lahan Sawah Indonesia Bertambah Jadi 7,4 Juta Ha. https://www.liputan6.com/. (23 Juli 2020).

Hanif dan Andi (2011). Studi Pemanfaatan Biogas Sebagai Pembangkit Listrik 10 Kw Kelompok Tani Mekarsari Desa Dander Bojonegoro Menuju Desa Mandiri Energi. Fakultas Teknologi Industri. ITS Surabaya.

Harsono, P. (2012). Mulsa Organik: Pengaruhnya terhadap Lingkungan Mikro, Sifat Kimia Tanah dan Keragaan Cabai Merah di Tanah Vertisol Sukoharjo pada Musim Kemarau. J. Hort. Indonesia, 3 (1), 35-41 
Hidayat, M., Marjono, Marsudi, \& Gunanto, A. (2006). Evaluasi Kinerja Teknis Mesin Pencacah Hijauan Pakan Ternak. Jurnal Injiniring Pertanian, 4 (2), 61-64.

Hidayat, N. (2014). Karakteristik dan Kualitas Silase Rumput Raja Menggunakan Berbagai Sumber dan Tingkat Penambahan Karbohidrat Fermentable. Agripet, 14, (1), 42-49.

Kartikawati, R. dan Nursyamsi, D. (2013). Pengaruh Pengairan, Pemupukan, Dan Penghambat Nitrifikasi Terhadap Emisi Gas Rumah Kaca Di Lahan Sawah Tanah Mineral. Ecolab, 7 (2), 49 108

Mena, H.F., Nesme, T., and Pallerin, S. (2016). Towards an Agro-Industrial Ecology: A review of nutrient flow modelling and assessment tools in agro-food systems at the local scale. Science of Total Environmental, 543, 467-479.

Oginawati, K., Khoirunnisa, R., Hijrah, S.N. (2013). Pemanfaatan Limbah Peternakan Berupa Urine dan Feses Sapi Sebagai Material Penyubur. Laporan Pengabdian LPPM: Institut Teknologi Bandung.

Partiwiningrum, A. Pemanfaatan Limbah Untuk Peningkatan Perekonomian Perdesaan. https://ugm.ac.id/. (23 Juli 2020)

PERATURAN MENTERI PERTANIAN RI No. 80 tahun 2011.

Saputra, L. (2017). Pengaruh Limbah Peternakan Sapi Terhadap Kualitas Air Tanah Untuk Kebutuhan Air Minum. Skripsi. Universitas Muhammadiyah Surakarta, Surakarta.

Sihombing (2000). Teknik Pengelolaan Limbah Kegiatan/Usaha Peternakan. Pusat Penelitian Lingkungan Hidup Lembaga Penelitian, Institut Pertanian Bogor. Bogor.

UPVAP-Unit Pelayanan Veteriner dan Analisis Proksimat (2016). Kedokteran Hewan. Universitas Airlangga. Surabaya. 